\title{
FREQUENCY OF CARBOHYDRATE METABOLISM DISORDERS IN DAY-CARE PATIENTS WITH BORDERLINE FASTING BLOOD SUGAR LEVELS AND AT LEAST ONE RISK FACTOR FOR DIABETES MELLITUS
}

Boeva $\mathrm{W}^{1} \bowtie$, Boeva $\mathrm{TA}^{2}$, Zavyalov $\mathrm{AN}^{3}$

${ }^{1}$ Federal Clinical Centre of High Medical Technologies, Moscow Region, Novogorsk, Russia

2 Tambov Central Regional Hospital,

Pokrovo Prigorodnoe Rural Settlement, Russia

Pirogov Russian National Research Medical University, Moscow, Russia

In order to assess the diagnosis of carbohydrate metabolism disorders, day care patients from Tambov central regional hospital were investigated. The study was conducted during 6 months in 2018. The study included 91 patients and allowed the diagnosis of type 2 diabetes mellitus (DM) in 31 (34.0\%) cases, 6 (6.5\%) impaired fasting glucose and $22(24.1 \%)$ impaired glucose tolerance. This survey highlighted the necessity to expand the screening populations at risk for developing type 2 diabetes. The rational for the 75-gram oral glucose tolerance test for all individuals with fasting plasma glucose $\geq 5.6 \leq 6.0 \mathrm{mmol} / \mathrm{l}$ and having one or more risk factors for developing type 2 diabetes and / or metabolic syndrome is shown. Among these categories diabetes was detected in $4.3 \%$, and prediabetes in $14.4 \%$ of cases.

Keywords: diabetes mellitus type 2, impaired fasting glucose, impaired glucose tolerance, screening, fasting venous plasma glucose, prediabetes

Author contribution: all authors participated in conceiving and planning the study, collected and analyzing the data. Boeva W prepared the study for publication. Compliance with ethical standards: the study was approved by the Ethics Committee of Pirogov Russian Medical Research Medical University (Protocol 176 dated June 25, 2018). All patients gave informed consent to participate.

$\triangle$ Correspondence should be addressed: Valentina V. Boeva

Ivanovskaya 3, Novogorsk, Moscow region, 141435; BoevaW@yandex.ru

Received: 20.01.2019 Accepted: 12.03.2019 Published online: 15.03.2019

DOI: $10.24075 /$ brsmu.2019.014

\section{ЧАСТОТА НАРУШЕНИЙ УГЛЕВОДНОГО ОБМЕНА У ПАЦИЕНТОВ ДНЕВНОГО СТАЦИОНАРА С ПОГРАНИЧНЫМИ ЗНАЧЕНИЯМИ ГЛИКЕМИИ НАТОЩАК И ХОТЯ БЫ ОДНИМ ФАКТОРОМ РИСКА РАЗВИТИЯ САХАРНОГО ДИАБЕТА}

\author{
В. В. Боева ${ }^{1}$, Т. А. Боева² , А. Н. Завьялов ${ }^{3}$
}

1 Федеральный клинический центр высоких медицинских технологий Федерального медико-биологического агентства России, Московская область, городской округ Химки, микрорайон Новогорск, Россия

2 Тамбовское областное государственное бюджетное учреждение здравоохранения «Тамбовская Центральная районная больница»,

Тамбовская область, Тамбовский район, с. Покрово-Пригородное, Россия

${ }^{3}$ Российский национальный исследовательский медицинский университет имени Н. И. Пирогова, Москва, Россия

С целью оценки диагностики нарушений углеводного обмена проведено обследование пациентов, поступивших в дневной стационар Тамбовского областного государственного бюджетного учреждения здравоохранения (ТОГ БУЗ) «Тамбовская Центральная районная больница» в период 6 месяцев 2018 г. Проведенное в рамках дневного стационара обследование 91 человека позволило выявить у 31 (34,0\%) человека сахарный диабет 2-го типа (СД), у 6 (6,5\%) нарушенную гликемию натощак и у 22 (24,1\%) нарушенную толерантность к глюкозе. Данное обследование показало необходимость расширения популяции скрининга в группах риска по развитию сахарного диабета 2 типа. Дано обоснование проведения перорального теста толерантности с 75 г глюкозы всем лицам с глюкозой венозной плазмы натощак $\geq 5,6 \leq 6,0$ ммоль/л, имеющим один или более факторы риска развития СД 2 типа и/или метаболический синдром: среди данной категории СД был выявлен в 4,3\%, а предиабет - в 14,4\% случаев.

Ключевые слова: сахарный диабет 2 типа, нарушенная гликемия натощак, нарушенная толерантность к глюкозе, скрининг, глюкоза венозной плазмы натощак, предиабет

Информация о вкладе авторов: В. В. Боева - анализ литературы, планирование исследования, анализ и интерпретация данных; Т. А. Боева — анализ литературы, планирование исследования, анализ и сбор данных; А. Н. Завьялов - анализ литературы, анализ и интерпретация данных.

Соблюдение этических стандартов: этический комитет ФГБОУ ВО РНИМУ им. Н. И. Пирогова Минздрава России; №176 от 25 июня 2018 г.

$\triangle$ Для корреспонденции: Валентина Владимировна Боева

ул. Ивановская, д. 3, Новогорск, Московская обл., 141435; BoevaWV@yandex.ru

Статья получена: 20.01.2019 Статья принята к печати: 12.03.2019 Опубликована онлайн: 15.03.2019

DOI: $10.24075 /$ vrgmu.2019.014

Diabetes mellitus (DM) is a major public health concern that has serious social implications. By the end of 2017, type 2 DM had been diagnosed in 425 million of the world population. By 2045, this number will have reached 629 million. It is estimated that 212.4 million people worldwide do not know that they have type 2 DM [1]. In January 2018, the National Diabetes Registry reported that of 4.6 million Russian citizens diagnosed with DM, 4.1 million had type 2 DM [2]. Extrapolated results of the NATION cross-sectional study conducted in Russia suggest that about 20.7 million Russian residents are prediabetic and another 4.2 million do not know that they already have type 2
DM. Thus, the actual prevalence of type $2 \mathrm{DM}$ in Russia is at least 5.5\% (8 million people); 19.3\% of Russians are prediabetic. The current situation with diabetes poses a serious threat to public health: at least $50 \%$ of the population do not know they are ill, do not receive any treatment and, therefore, are at high risk for complications [3, 4].

Between 2007 and 2012, the number of Russian patients with DM was increasing steadily by $6.23 \%$ (or 173,640) a year [5].

According to the report of the Federal Diabetes Mellitus Registry published on January 17,2018 , the prevalence of type 2 DM in Tambov region was 4,044.3 per 100,000 population, 
ranking second among 85 Russian regions [2]. Therefore, Tambov region could be a good location for a pilot study of type 2 DM epidemiologic trends in Russia. The analysis of type 2 DM in the adult population of Tambov region demonstrates that its prevalence was increasing gradually between 2011 and 2018, from 1600,6 and 2477,0 per 100,000 population. In the first place, this trend is associated with increased primary incidence of type 2 DM that had risen from 208.1 to 242.6 by 2018 [6].

Obviously, prevention and timely diagnosis of type $2 \mathrm{DM}$ is becoming a nationwide concern. The prevalence of the disease remains high; it also tends to grow over time. at present, screening for DM in the groups at risk is not as effective as it should be. A systemic population approach is needed that will, among other things, seek to expand screening programs both locally and statewide.

As part of the Federal Targeted Program on the Prevention and Control of Major Diseases, the Diabetes Mellitus Project was being implemented in Russia from 2007 to 2012. The project aimed at improving life expectancy and reducing complications in patients with DM, i. e. it focused on secondary prevention. There are no statewide programs for primary prevention of type 2 DM launched to stop progression of prediabetes into diabetes.

The term "prediabetes" was proposed by the World Health Organization in 1965. Since 1999, the terms "prediabetes" and "carbohydrate metabolism disorder" have been used to describe the two health conditions preceding DM: impaired fasting glucose (IFG) and impaired glucose tolerance (IGT), as well as the combination of the two, highlighting a high risk for type 2 DM in the affected patients (4-9\% cases a year) $[3,7]$.

Because at least $50 \%$ of patients with type 2 DM do not know they have it, we could be facing a situation when the criteria for patient eligibility for DM screening are not sufficiently sensitive.

The prevalence of metabolic syndrome (MS) varies from 14 to $24 \%$ in the general population [8]. The symptoms of this condition are observed in $20-50 \%$ of the working population of the developed countries [9]. In Russia, MS is diagnosed in 30\% of adults over 30 , and the number of such patients is growing steadily [10]. In $90 \%$ of cases, type 2 DM is accompanied by abdominal obesity and is a clinical outcome of MS.

Timely diagnosis of type $2 \mathrm{DM}$ is still a challenge. In spite of the increasing availability of diagnostic techniques, the diagnosis is often delayed until the time when complications have already cropped up, which typically occurs within several years after the actual onset of the disease. Timely diagnosis of carbohydrate metabolism disorders could curb the incidence of type $2 \mathrm{DM}$, prevent complications or disabilities, and reduce the financial burden on the public healthcare system. Therefore, further research into DM is a matter of paramount importance.

\section{METHODS}

This cross-sectional noninterventional observational cohort study was conducted in 91 individuals (24 males and 67 females) aged 32 to 79 years. The participants were selected from 840 patients of Tambov Central District Hospital who had presented at the day-care unit over the period of 6 months in 2018. The following inclusion criteria were applied:

1. Fasting plasma glucose (FPG) of at least $5.6 \mathrm{mmol} / \mathrm{L}$;

2. At least one risk factor (RF) for type 2 DM [1], including:

- age over 45 years;

- excess weight or obesity $\left(\mathrm{BMl} \geq 25 \mathrm{~kg} / \mathrm{m}^{2}\right)$;

- abdominal obesity (waist circumference $>94 \mathrm{~cm}$ in men and $>80 \mathrm{~cm}$ in women);

- elevated blood pressure $\geq 140 / 90 \mathrm{mmHg}$ or antihypertensive medication therapy in progress;

- hypercholesterolemia (LDP $\geq 1.8 \mathrm{mmol} / \mathrm{L})$;

- cardiovascular disorders;

- previously detected impaired fasting glucose or impaired glucose tolerance;

- family history of DM.

All patients gave written informed consent to participate.

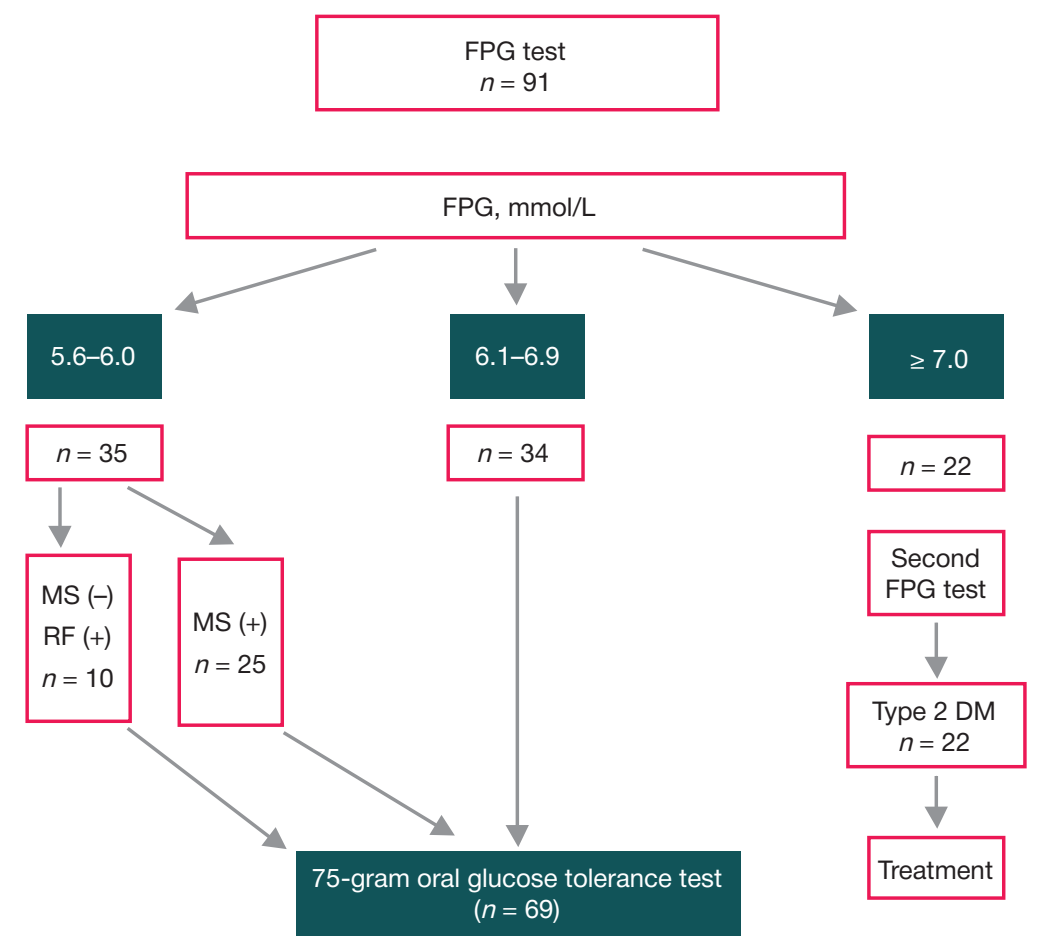

Fig. 1. The study included 91 patients, who were then distributed into 3 groups depending on their blood sugar levels. Patients with $F P G \geq 7.0$ mmol/L (measured in two repeated tests) were diagnosed with type $2 \mathrm{DM}$ and prescribed adequate treatment. Patients with FPG between 6.1 and $6.9 \mathrm{mmol} / \mathrm{L}$ underwent an oral glucose tolerance test (OGTT). Patients with FPG between 5.6 and $6.0 \mathrm{mmol} / \mathrm{L}$ who were at risk for developing type 2 DM and metabolic syndrome also underwent OGGT. FPG — fasting plasma glucose 
The following exclusion criteria were applied: type 2 $\mathrm{DM}$; type $1 \mathrm{DM}$; an exacerbation of any chronic disease; inflammation; a severe comorbidity; FPG $<5.6 \mathrm{mmol} / \mathrm{L}$.

The patients were examined for the symptoms of metabolic syndrome and assessed for the risk of developing type $2 \mathrm{DM}$. According to IDF (2005), the main clinical manifestations of MS in Caucasian patients include abdominal obesity (waist circumference $>94 \mathrm{~cm}$ in men and $>80 \mathrm{~cm}$ in women) and two or more factors listed below [11]:

1) elevated triglycerides $>1.7 \mathrm{mmol} / \mathrm{L}$ or lipid-lowering therapy in progress;

2) low HDL $(<1.03 \mathrm{mmol} / \mathrm{L}$ in men and $<1.29 \mathrm{mmol} / \mathrm{L}$ in women) or lipid-lowering therapy in progress;

3) elevated blood pressure $\geq 130 / 85 \mathrm{mmHg}$ or antihypertensive therapy in progress;

4) fasting blood sugar $\geq 5.6 \mathrm{mmol} / \mathrm{L}$ or previously diagnosed type 2 diabetes.

All patients with FPG falling in the range between 5.6 and 6.0, MS or at least one risk factor for type $2 \mathrm{DM}$ underwent a 75-gram oral glucose tolerance test (OGTT). The schematic representation of the study is provided in Fig. 1.

The obtained data were processed in Statistica ver 6.1 (StatSoft; Russia). Because the Kolmogorov-Smirnov normality test revealed non-normal distribution, the nonparametric Mann-Whitney U-test was applied.

\section{RESULTS}

Of 91 patients included in the analysis, 22 (24.2\%) had presented with complaints of fatigue, dry mouth, increased thirst, frequent urination, itchy skin, weight gain, or unstable blood pressure. Type 2 DM was confirmed in 22 patients (4 men and 18 women) aged 34 to 69 years whose FPG was $\geq$ $7.0 \mathrm{mmol} / \mathrm{L}$ in two repeated tests.

Thirty-five patients (38.4\%) had FPG in the range from 5.6 to $6.0 \mathrm{mmol} / \mathrm{L}$, metabolic syndrome and at least one risk factor for developing type 2 DM. In 34 patients (37.3\%), FPG ranged from 6.1 to $6.9 \mathrm{mmol} / \mathrm{L} ; 97.0 \%$ of such patients (or 33 out of 34) had symptoms of metabolic syndrome. An oral glucose tolerance test was ordered for all those patients.

Carbohydrate metabolism disorders were observed in $64.8 \%(n=59)$ of the patients with borderline fasting blood sugar and at least one risk factor for type $2 \mathrm{DM} ; 34.0 \%(n=31)$ of those individuals had never been diagnosed with type 2 DM before, and $30.7 \%(n=28)$ were prediabetic. Twenty-two (24.1\%) prediabetic patients had IGT.

All patients with new-onset type $2 \mathrm{DM}(n=31)$ had signs of metabolic syndrome. In 9 patients, type 2 DM was diagnosed based on OGTT.

Figure 3 shows the distribution of the patients depending on the severity of carbohydrate metabolism disorders revealed by OGTT in the group of 35 individuals with initial FPG between 5.6 and $6.0 \mathrm{mmol} / \mathrm{L}$.
Figure 4 shows the distribution of the patients depending on the severity of carbohydrate metabolism disorders revealed by OGTT in the group of 34 patients with initial FPG between 6.1 and $6.9 \mathrm{mmol} / \mathrm{L}$.

Clinical and demographic characteristics of the patients grouped by the severity of carbohydrate metabolism disorders $(n=91)$ are shown in Table 1.

OGTT conducted in 69 participants revealed that $13.0 \%$ (9 patients) had type 2 DM, 31.8\% (22 patients) had IGT, and $8.7 \%$ (6 patients) had IFG. Normal fasting blood sugar levels were observed in $46.3 \%$ (32) of the participants (Table 2). Interestingly, the frequency of IFG cases was low.

Of 9 patients with new-onset type 2 DM, 3 had FPG between 5.6 and $6.0 \mathrm{mmol} / \mathrm{L}$ and 6 had FPG between 6.1 and $6.9 \mathrm{mmo} / \mathrm{L}$.

The distribution of the patients depending on the severity of carbohydrate metabolism disorders (OGTT) in the groups with initial IFG levels ranging from 5.6 to $6.0 \mathrm{mmol} / \mathrm{L}(n=35)$ and from 6.1 to $6.9 \mathrm{mmol} / \mathrm{L}(n=34)$ is shown in Table 2 .

OGTT demonstrated that $2.8 \%$ of the participants from the group with initial FPG between 5.6 and $6.0 \mathrm{mmol} / \mathrm{L}$ had IFG; the frequencies of IGT and type 2 DM cases were $11.5 \%$ and $4.3 \%$, respectively. Thus, there were $14.4 \%$ prediabetic patients in the studied cohort.

Glucose tolerance was significantly less prevalent in the patients with FPG ranging from 6.1 to $6.9 \mathrm{mmol} / \mathrm{L}$.

Most patients were over 45 years of age. This was true for $100 \%$ of the patients in the IFG and IGT groups and for $84.3 \%$ and $90.3 \%$ of the patients in the groups with normal carbohydrate metabolism and new-onset type 2 DM, respectively. All groups were dominated by overweight or obese patients. All patients had increased waist circumference. No significant differences were observed in the number of patients with a family history of type 2 DM (Table 1).

The number of patients with elevated blood pressure was significantly higher in the group with normal carbohydrate metabolism and prediabetes in comparison with the group with new-onset type 2 DM $(p<0.05)$.

No significant differences were detected between the groups in terms of lipid counts, chronic pancreatitis or the history of cardiovascular diseases ( $p>0.05$ ).

It should be noted that there were more patients with a history of elevated glucose levels in the group with new-onset DM $(p>0.05)$. Of 8 patients, only 2 had had their carbohydrate metabolism disorder and impaired glucose tolerance verified. Those patients had been receiving metformin for no longer than one year before the study and terminated the drug without consulting their physician. No diagnostic tests had been previously performed in the rest of the patients to assess their metabolic status.

Among 4 patients with IGT who had been diagnosed with elevated blood sugar between 2013 and 2018, one woman had been taking metformin for 6 years continuously $(500 \mathrm{mg}$ per day). This allowed her to stay at the prediabetic stage

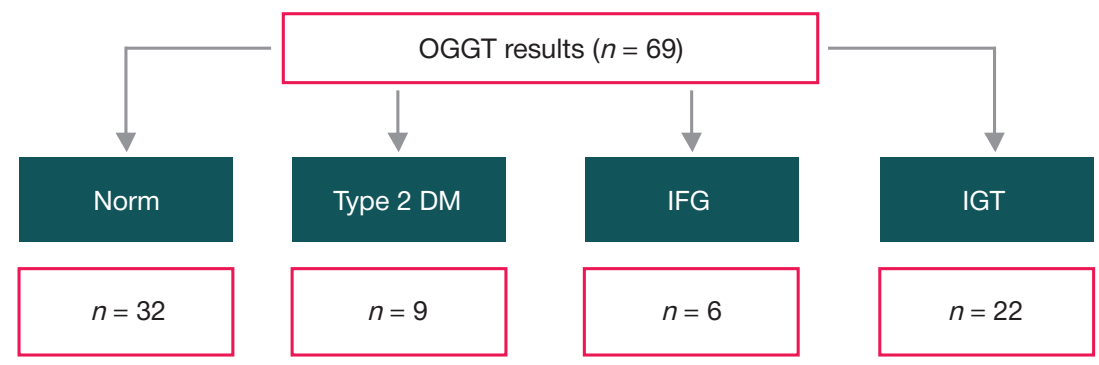

Fig. 2. The overall distribution of the patients depending on the severity of carbohydrate metabolism disorders revealed by OGTT. IFG - impaired fasting glucose; IGT — impaired glucose tolerance; OGTT — oral glucose tolerance test 
without progressing to diabetes. No patients from our cohort had been recommended to undergo a 75-gram oral glucose tolerance test before.

Two patients with IFG had been diagnosed with elevated blood sugar (up to $6.5 \mathrm{mmol} / \mathrm{L}$ ) within a year preceding this study, but had chosen not to consult an endocrinologist. The oral glucose tolerance test was conducted when those patients presented at the day-care unit with unstable blood pressure.

All patients with carbohydrate metabolism disorder were examined by an endocrinologist. The patients with new-onset type 2 DM were prescribed glucose-lowering therapy.

The patients with IFG and IGT were prescribed metformin at a starting dose of $500 \mathrm{mg}$ before bed to prevent type $2 \mathrm{DM}$ and given recommendation on maintaining blood sugar levels. The patients with normal blood sugar were recommended to undergo a control test in a year and to consult an endocrinologist if their glucose levels should rise.

The patients with normal glucose tolerance were given dietary and weight loss recommendations. They were also recommended an antihypertensive therapy and statins for treating dyslipidemia.

Summing up, OGTT should be ordered for the patients with FPG in the range between 5.6 and $6.0 \mathrm{mmol} / \mathrm{L}$ who are at risk for developing DM and/or metabolic syndrome.

\section{DISCUSSION}

The incidence of type 2 DM in 91 study participants who had borderline fasting glucose levels and at least one risk factor for this condition was $34.0 \%(n=31)$. IFG was diagnosed in $6.5 \%$ $(n=6)$ of patients and IGT, in $24.1 \%$ patients $(n=22)$. Thirtytwo participants (35.1\%) had normal glucose tolerance.

According to the NATION study, about 21 million Russian residents aged 20 to 79 years are prediabetic; another 4.2 million do not know they have type 2 DM [3]. In this study, a glycated hemoglobin test was used as a diagnostic criterium. This approach is an alternative to [12]; it has its advantages (higher specificity for type 2 DM) and drawbacks (lower specificity for prediabetic conditions) $[13,14]$.

Because at least $50 \%$ of patients with type 2 DM do not know they have it, we could be facing a situation when the criteria for patient eligibility for DM screening are not sufficiently sensitive. Depending on the country, different criteria are applied to identify groups at risk for type 2 DM. The Canadian Diabetes Association highlights the necessity of conducting screening for type $2 \mathrm{DM}$ in all patients older than 40 regardless of the presence of specific risk factors [15]. The criteria proposed by the American Diabetes Association (ADA) include age over 45 years (regardless of the risk factors present) or

Table 1. Clinical and demographic characteristics of patients

\begin{tabular}{|l|c|c|c|c|}
\hline \multicolumn{1}{|c|}{ Parameters } & $\begin{array}{c}\text { Norm } \\
(n=32)\end{array}$ & $\begin{array}{c}\text { IFG } \\
(n=6)\end{array}$ & $\begin{array}{c}\text { IGT } \\
(n=22)\end{array}$ & $\begin{array}{c}\text { Type 2 DM } \\
(n=31)\end{array}$ \\
\hline Men & $10(31.2 \%)$ & $3(50.0 \%)$ & $5(22.7 \%)$ & $6(19.3 \%)$ \\
\hline Women & $22(68.7 \%)$ & $3(50.0 \%)$ & $17(77.2 \%)$ & $25(80.6 \%)$ \\
\hline Age $\geq 45$ years & $27(84.3 \%)$ & $6(100 \%)$ & $22(100 \%)$ & $28(90.3 \%)$ \\
\hline Family history of type 2 DM & $2(6.2 \%)$ & $1(16.6 \%)$ & $6(27.2 \%)$ & $7(22.5 \%)$ \\
\hline BMI $\geq 25$ & $30(93.7 \%)$ & $6(100 \%)$ & $21(95.4 \%)$ & $31(100 \%)$ \\
\hline WC $>80$ cm (women) & $22(100 \%)$ & $3(100 \%)$ & $17(100 \%)$ & $25(100 \%)$ \\
\hline WC $>94$ cm (men) & $10(100 \%)$ & $3(100 \%)$ & $5(100 \%)$ & $6(100 \%)$ \\
\hline Hypertension & $32(100 \%)^{*}$ & $6(100 \%)$ & $22(100 \%)^{*}$ & $25(80.6 \%)$ \\
\hline Hypercholesterolemia & $21(65.6 \%)$ & $6(100 \%)$ & $15(68.1 \%)$ & $18(58.0 \%)$ \\
\hline Chronic pancreatitis & $3(9.3 \%)$ & $1(16.6 \%)$ & $3(13.6 \%)$ & $5(16.1 \%)$ \\
\hline Cardiovascular diseases & $9(28.1 \%)$ & $2(33.3 \%)$ & $4(18.1 \%)$ & $8(25.8 \%)$ \\
\hline AMl & $3(9.3 \%)$ & $1(16.6 \%)$ & $2(9.0 \%)$ & $3(9.6 \%)$ \\
\hline ACE & $3(9.3 \%)$ & $0(0 \%)$ & $1(4.5 \%)$ & $0(0 \%)$ \\
\hline TIA & $1(3.1 \%)$ & $0(0 \%)$ & $0(0 \%)$ & $2(6.4 \%)$ \\
\hline Peripheral artery disease & $2(6.2 \%)$ & $1(16.6 \%)$ & $1(4.5 \%)$ & $3(9.6 \%)$ \\
\hline History of hyperglycemia & $3(9.3 \%)$ & $2(33.3 \%)$ & $4(18.1 \%)$ & $8(25.8 \%)$ \\
\hline
\end{tabular}

Note: * — differences are significant, $p<0.05$; BMI — body mass index; IFG — impaired fasting glucose; IGT— impaired glucose tolerance; AMI — acute myocardial infarction; ACE — acute cerebrovascular event; WC — waist circumference; OGTI - oral glucose tolerance test; DM — diabetes mellitus; TIA — transient ischemic attack.

Table 2. The distribution of the patients depending on the severity of carbohydrate metabolism disorders (OGTT)

\begin{tabular}{|c|c|c|c|c|}
\hline \multirow{2}{*}{ Carbohydrate metabolism } & \multicolumn{2}{|c|}{$n=69$} & \multirow{2}{*}{$\times 2 / \varphi$} & \multirow{2}{*}{$p$} \\
\hline & FPG 5.6-6.0 & FPG 6.1-6.9 & & \\
\hline Normal & $22(31.8 \%)$ & $10(14.4 \%)$ & 6.5 & $0.011^{*}$ \\
\hline IFG & $2(2.8 \%)$ & $4(5.7 \%)$ & 0.43 & $>0.05$ \\
\hline IGT & $8(11.5 \%)$ & $14(20.2 \%)$ & 1.9 & 0.17 \\
\hline DM & $3(4.3 \%)$ & $6(8.6 \%)$ & 0.3 & $>0.05$ \\
\hline
\end{tabular}

Note: * - differences are significant, $p<0.05$; FPG — fasting plasma glucose; IFG — impaired fasting glucose; IGT— impaired glucose tolerance; OGT- oral glucose tolerance test; DM - diabetes mellitus. In the subgroup of patients with FPG levels ranging from 5.6 to 6.0 mmol/L, there were $2.8 \%$ cases of IFG, $11.5 \%$ cases of IGT and $4.3 \%$ cases of type 2 DM (based on OGTT results). Thus, the frequency of prediabetic conditions in the subgroup was $14.4 \%$. The frequency of IGT was significantly lower in the subgroup with FPG between 6.1 and $6.9 \mathrm{mmpl} / \mathrm{L}$. 


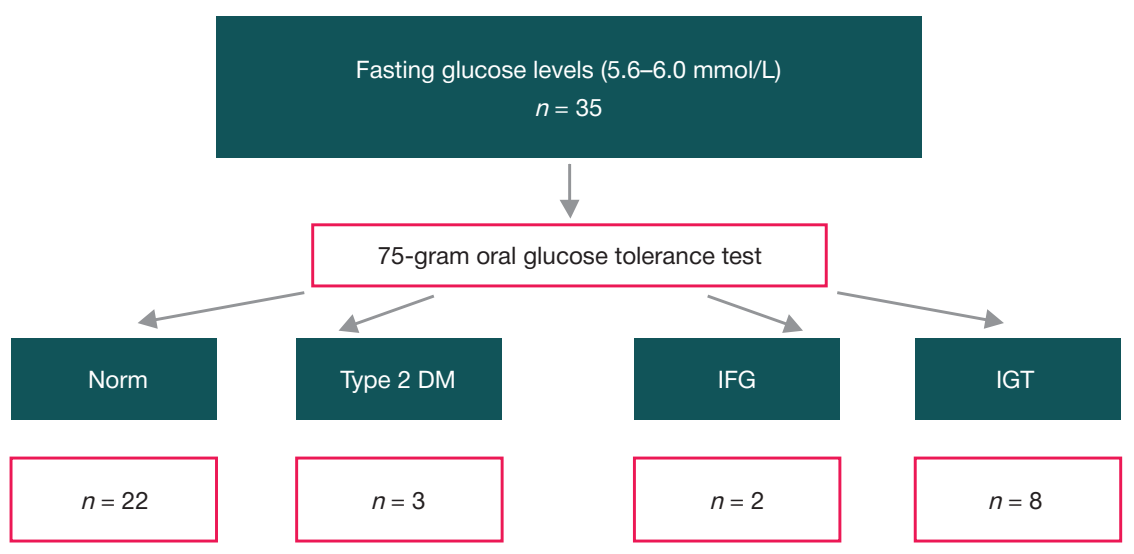

Fig. 3. The distribution of the patients depending on the severity of carbohydrate metabolism disorders revealed by OGTT in the group of 35 individuals with initial FPG between 5.6 and $6.0 \mathrm{mmol} / \mathrm{L}$. IFG — impaired fasting glucose; IGT — impaired glucose tolerance; OGTT — oral glucose tolerance test

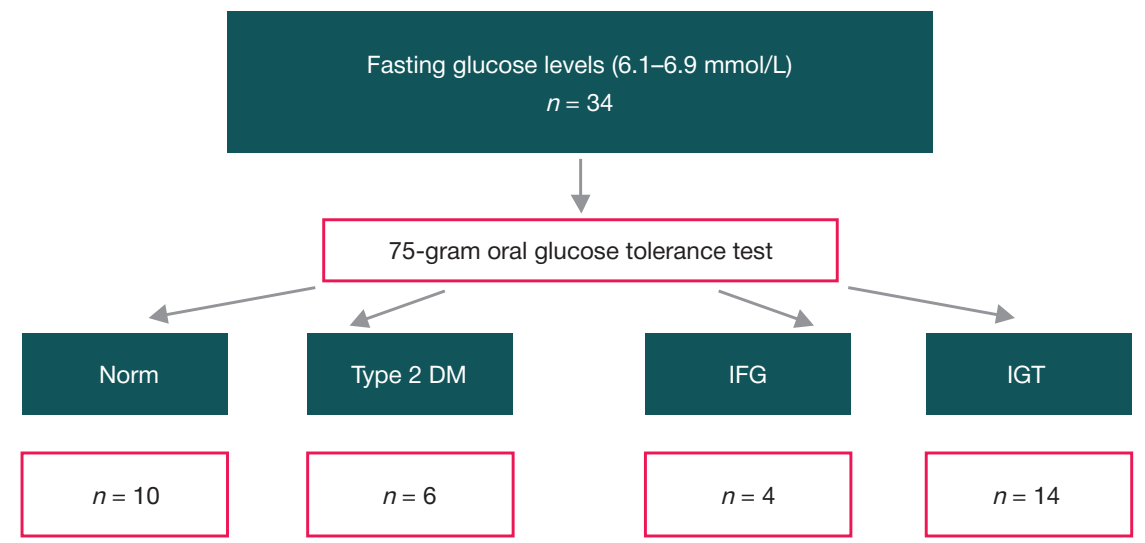

Fig. 4. The distribution of the patients depending on the severity of carbohydrate metabolism disorders revealed by OGTT in the group of 34 individuals with initial FPG between 6.1 and $6.9 \mathrm{mmol} / \mathrm{L}$. IFG — impaired fasting glucose; IGT — impaired glucose tolerance; OGTT — oral glucose tolerance test

age younger than 45 years + the presence of the risk factors

[16]. European clinical guidelines suggest using a questionnaire to assess the risk for type $2 \mathrm{DM}$ and then conduct screening in the populations at moderate and high risk for the disease [17]. Such differences in the criteria for patient eligibility have economic and epidemiological causes.

Our study has demonstrated the need for covering broader populations in the groups at risk for type $2 \mathrm{DM}$. We have provided a rationale for performing a 75-gram oral glucose tolerance test in all individuals with FPG between 5.6 and 6.0 $\mathrm{mmol} / \mathrm{L}$ who have at least one risk factor for type $2 \mathrm{DM}$ and/ or metabolic syndrome. In our study, DM was diagnosed in $4.3 \%$ of such patients; another $14.4 \%$ were prediabetic. Early diagnosis of carbohydrate metabolism disorders and timely medication therapy would help to prevent development of
DM 2 in prediabetic patients. Timely diagnosis and treatment of type 2 DM could prevent possible complications.

\section{CONCLUSIONS}

1) Screening for carbohydrate metabolism disorders in patients with borderline fasting glucose has revealed that the actual prevalence of type $2 \mathrm{DM}$ is three times higher than reported. 2) Screening should be performed in patients at risk for type 2 DM using a FPG test even in the absence of clinical manifestations of diabetes in such patients. 3) A 75-gram oral glucose tolerance test should be performed in all patients with metabolic syndrome and/or one or more risk factors for type 2 DM with FPG between 6.1 and $6.9 \mathrm{mmol} / \mathrm{L}$, as well as those who have FPG ranging from 5.6 to $6.0 \mathrm{mmol} / \mathrm{L}$.

\section{References}

1. International Diabetes Federation. Diabetes Atlas, $8^{\text {th }}$ ed, 2017.

2. State Diabetes Register. Professional All-Russian Resource on Diabetes Nosology under the auspices of Endocrinology Research Center/ http://diaregistry.ru/content/o-proekte.html\#content Verified on May 28, 2018.

3. Dedov II, Shestakova MV, editors. Algorithms of Specialized Medical Care for Diabetes Mellitus Patients. 8-th Edition. Moscow, 2017.

4. Dedov II, Shestakova MV, Galstyan GR. Prevalence of Type 2 Diabetes Mellitus in Adult Russian Population (NATION study). Diabetes Mellitus. 2016; 19 (2): 104-112.
5. Results of implementation of the subprogramme «Diabetes Mellitus» of the Federal Target Program «Prevention and Control of Socially Significant Diseases in 2007-2012». Edited by Dedov II., Shestakova MV. Diabetes Mellitus. 2013; Special edition 2S: 2-48.

6. Tambov Regional State Budgetary Establishment «Technical and Material Support Center of Healthcare Institutions Activities». Form No. 12. Order of the Federal State Statistics Service: On form approval dated 2016 July 21; 355.

7. Starodubova AV., Chervyakova YuV., Kopelev AA., Alieva AM. Possibilities of Drug Correction of Metabolic Disorders and Prevention of Diabetes Mellitus in Case of Carbohydrate 
Metabolism Disorder. General Medicine. 2015; (3): 59-65.

8. van Vliet-Ostaptchouk J, Nuotio M, Slagter S, Doiron D, Fischer K, Foco $\mathrm{L}$, et al. The prevalence of metabolic syndrome and metabolically healthy obesity in Europe: a collaborative analysis of ten large cohort studies. BMC Endocrine Disorders. 2014; 14 (1): 9.

9. Simonenko VB, Medvedev IM, Tolmachev W. Patogeneticheskie aspekty arterial'noj gipertenzii pri metabolicheskom sindrome/ Klinich. medicina. 2011; 89 (1): 49-51.

10. Ivashkin VT, Drapkina OM, Korneeva ON. Klinicheskie varianty metabolicheskogo sindroma. M: Medicinskoe informacionnoe agentstvo. 2011; 220.

11. International Diabetes Federation (IDF): Consensus on the Criteria of Metabolic Syndrome. Obesity and Metabolism. 2005; (3): 47-9.

12. Khetan A, Rajagopalan S, Prediabetes, Can J Cardiol. 2018 May; 34(5): 615-23.

13. Yan $\mathrm{S}$, et al. Diagnostic accuracy of $\mathrm{HbA} 1 \mathrm{c}$ in diabetes between Eastern and Western. Eur J Clin Invest. 2013 Jul; 43(7): 716-26.
14. Barry E. Efficacy and effectiveness of screen and treat policies in prevention of type 2 diabetes: systematic review and metaanalysis of screening tests and interventions. BMJ. 2017 Jan; 4; 356: i6538.

15. Goldenberg R, Punthakee Z. Canadian Diabetes Association 2013 clinical practice guidelines for the prevention and management of diabetes in Canada: definition, classification and diagnosis of diabetes, prediabetes and metabolic syndrome. Can J Diabetes. 2013; 37

16. Classification and diagnosis of diabetes. Diabetes Care. 2017; (40): 11-24

17. ESC Guidelines on diabetes, pre-diabetes, and cardiovascular diseases developed in collaboration with the EASD: the task force on diabetes, pre-diabetes, and cardiovascular diseases of the European Society Of Cardiology (ESC) and Developed in Collaboration With The European Association For The Study Of Diabetes (EASD). Eur Heart J. 2013; (34): 3035-87.

\section{Литература}

1. International Diabetes Federation. Diabetes Atlas, $8^{\text {th }}$ ed, 2017.

2. Государственный регистр сахарного диабета. Профессиональный всероссийский ресурс по нозологиям диабета под эгидой Эндокринологического Научного Центра. Доступно по ссылке: http://diaregistry.ru/content/o-proekte.html\#content. Проверено 28.11.18.

3. Дедов И. И., Шестакова М. В., редакторы. Алгоритмы специализированной медицинской помощи больным сахарным диабетом. 8-е издание. М., 2017.

4. Дедов И. И., Шестакова М. В., Галстян Г. Р. Распространенность сахарного диабета 2 типа у взрослого населения России (исследование NATION). Сахарный диабет. 2016; 19 (2): 104-12.

5. Результаты реализации подпрограммы «Сахарный диабет» Федеральной целевой программы «Предупреждение и борьба с социально значимыми заболеваниями 2007-2012 гг». Под ред. Дедова И. И., Шестаковой М. В. Сахарный диабет. 2013; Спецвыпуск 2S: 2-48.

6. Тамбовское областное государственное бюджетное учреждение «Центр материально-технического обеспечения деятельности учреждений здравоохранения». Форма №12. Приказ Росстата: Об утверждении формы от 21.07.2016; № 355.

7. Стародубова А. В., Червякова Ю. В., Копелев А. А., Алиева А. М. Возможности медикаментозной коррекции метаболических нарушений и профилактики сахарного диабета при нарушениях углеводного обмена. Лечебное дело. 2015; (3): 59-65.

8. van Vliet-Ostaptchouk J, Nuotio M, Slagter S, Doiron D, Fischer K, Foco $L$, et al. The prevalence of metabolic syndrome and metabolically healthy obesity in Europe: a collaborative analysis of ten large cohort studies. BMC Endocrine Disorders. 2014; 14 (1), 9.

9. Симоненко В. Б., Медведев И. М., Толмачев В. В.

Патогенетические аспекты артериальной гипертензии при метаболическом синдроме. Клиническая медицина. 2011; 89 (1): 49-51.

10. Ивашкин В. Т., Драпкина О. М., Корнеева О. Н. Клинические варианты метаболического синдрома. М.: Медицинское информационное агентство, 2011; с. 220.

11. Международная Федерация диабета (IDF): консенсус по критериям метаболического синдрома. Ожирение и метаболизм. 2005; (3): 47-9.

12. Khetan A, Rajagopalan S, Prediabetes. Can J Cardiol. 2018 May; 34 (5): 615-23.

13. Yan S. et al. Diagnostic accuracy of $\mathrm{HbA} 1 \mathrm{c}$ in diabetes between Eastern and Western. Eur J Clin Invest. 2013 Jul; 43 (7): 716-26.

14. Barry E. Efficacy and effectiveness of screen and treat policies in prevention of type 2 diabetes: systematic review and metaanalysis of screening tests and interventions. BMJ. 2017 Jan; 4; 356: i6538.

15. Goldenberg R, Punthakee Z. Canadian Diabetes Association 2013 clinical practice guidelines for the prevention and management of diabetes in Canada: definition, classification and diagnosis of diabetes, prediabetes and metabolic syndrome. Can J Diabetes. 2013; 37.

16. Classification and diagnosis of diabetes. Diabetes Care 2017; (40): 11-24

17. ESC Guidelines on diabetes, pre-diabetes, and cardiovascular diseases developed in collaboration with the EASD: the task force on diabetes, pre-diabetes, and cardiovascular diseases of the European Society Of Cardiology (ESC) and Developed in Collaboration With The European Association For The Study Of Diabetes (EASD). Eur Heart J. 2013; (34): 3035-87. 